
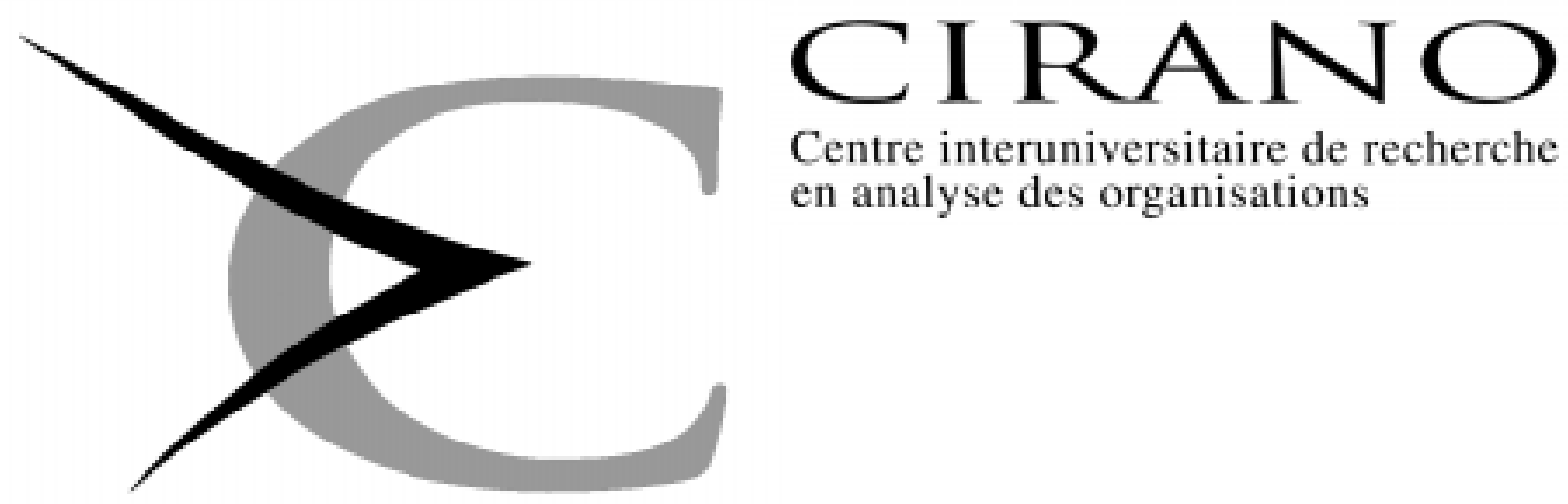

Centre interuniversitaire de recherche en analyse des organisations

Série Scientifique

Scientific Series

97s-11

Aggregation, Efficiency and

Mutual Fund Separation in Incomplete Markets

Jérôme B. Detemple, Piero Gottardi 


\section{CIRANO}

Le CIRANO est une corporation privée à but non lucratif constituée en vertu de la Loi des compagnies du Québec. Le financement de son infrastructure et de ses activités de recherche provient des cotisations de ses organisations-membres, d'une subvention d'infrastructure du ministère de l'Industrie, du Commerce, de la Science et de la Technologie, de même que des subventions et mandats obtenus par ses équipes de recherche. La Série Scientifique est la réalisation d'une des missions que s'est données le CIRANO, soit de développer l'analyse scientifique des organisations et des comportements stratégiques.

CIRANO is a private non-profit organization incorporated under the Québec Companies Act. Its infrastructure and research activities are funded through fees paid by member organizations, an infrastructure grant from the Ministère de l'Industrie, du Commerce, de la Science et de la Technologie, and grants and research mandates obtained by its research teams. The Scientific Series fulfils one of the missions of CIRANO: to develop the scientific analysis of organizations and strategic behaviour.

\section{Les organisations-partenaires / The Partner Organizations}

•École des Hautes Études Commerciales

-École Polytechnique

-McGill University

-Université de Montréal

-Université du Québec à Montréal

-Université Laval

-MEQ

-MICST

-Aveno.

-Banque Nationale du Canada

-Bell Québec

-Fédération des caisses populaires Desjardins de Montréal et de l'Ouest-du-Québec

-Hydro-Québec

-La Caisse de dépôt et de placement du Québec

-Raymond, Chabot, Martin, Paré

-Société d'électrolyse et de chimie Alcan Ltée

-Téléglobe Canada

-Ville de Montréal

Ce document est publié dans l'intention de rendre accessibles les résultats préliminaires de la recherche effectuée au CIRANO, afin de susciter des échanges et des suggestions. Les idées et les opinions émises sont sous l'unique responsabilité des auteurs, et ne représentent pas nécessairement les positions du CIRANO ou de ses partenaires.

This paper presents preliminary research carried out at CIRANO and aims to encourage discussion and comment. The observations and viewpoints expressed are the sole responsibility of the authors. They do not necessarily represent positions of CIRANO or its partners.

ISSN 1198-8177 


\title{
Aggregation, Efficiency and Mutual Fund Separation in Incomplete Markets"
}

\author{
Jérôme B. Detemple ${ }^{\dagger}$, Piero Gottardi $i^{*}$
}

\section{Résumé / Abstract}

\begin{abstract}
Cet article étudie les conditions requises pour l'agrégation, la séparation de portefeuille et la complétude effective des allocations compétitives dans les modèles d'équilibre général avec marchés incomplets où les agents ont des préférences et des distributions de dotations initiales générales. Nous montrons que ces propriétés sont distinctes. Les demandes peuvent agréger sans pour autant satisfaire la propriété de séparation de portefeuille et inversement. La séparation de portefeuille implique la complétude effective, tandis que l'agrégation ne l'implique pas. Les conséquences de ces propriétés pour la structure des équilibres sont discutées, et des généralisations du CAPM, du CAPM de consommation et du CAPM avec richesse non négociée émergent de l'analyse.

This paper studies the conditions for aggregation, portfolio separation and effective completeness of competitive allocations in general equilibrium models with incomplete markets in which agents have general preference and endowment distributions. We show that these properties are distinct. Demands may aggregate yet may fail to exhibit fund separation and conversely. Fund separation implies effective completeness while aggregation does not. The implications of these properties for the structure of equilibria are discussed, and generalizations of the CAPM, the consumption CAPM and the CAPM with nonmarketed wealth emerge from the analysis.
\end{abstract}

Mots Clés : Agrégation, efficience, séparation de portefeuille, marchés incomplets, préférences générales, dotations non-marchandées

Keywords : $\quad$ Aggregation, Efficiency, Mutual Fund Separation, Incomplete Markets, General Preferences, Nontraded Endowments

JEL : D52, G11, G12

\footnotetext{
*Correspondence Address: Jérôme B. Detemple, CIRANO, 2020 University Street, 25th floor, Montréal, Qc Canada H3A 2A5 Tel: (514) 985-4028 Fax: (514) 985-4039 e-mail: detemplj@ cirano.umontreal.ca Part of this work was completed while the authors were, respectively, visiting the Slaon School of Management, MIT, Cambridge, and Harvard University, Cambridge. An earlier version of this paper was presented at the Congress of the European Economic Association in Dublin, 1992. We wish to thank T. Hens, H. Polemarchakis for very useful comments. This work was supported in part by the Social Sciences and Humanities Research Council of Canada through strategic grant 804-96-0027, and by CNR at the University of Venice.

$\doteqdot$ McGill University and CIRANO

$\$$ Universita di Venezia and Trinity College, Cambridge
} 


\section{Introduction}

For several decades economists have attempted to characterize the structure and the behaviour of asset prices in competitive financial markets. The sole assumptions of rational, maximizing behaviour of agents and of perfectly competitive markets, however, impose very few restrictions on the aggregate demand function (Sonnenschein (1974), Debreu (1974), Mantel (1976); also Bottazzi and Hens (1996), Gottardi and Hens (1996) for an extension to incomplete markets), and hence on the relationship between asset prices and the "fundamentals" of the economy. This has stimulated an interest in more specialized economies in which the aggregate demand exhibits some structure, such as economies in which aggregation holds (a representative agent can be constructed), or mutual fund separation obtains.

When markets are complete a whole set of results can be obtained without special assumptions. For instance, arbitrage arguments produce explicit valuation formulas for various types of derivative securities such as options. The assumption that all risks are marketed, however, is very strong. It is then of interest to identify conditions under which markets are effectively complete, i.e. equilibria exhibit the same properties as when markets are complete.

In this paper we study the conditions for aggregation, portfolio separation and effective completeness in a general equilibrium model with incomplete markets in which agents have general preference and endowment distributions. Prior literature has mainly focused on the choice problem of agents with von NeumannMorgenstern (vNM) preferences and endowments only at the beginning of their lives. In this setting these three properties hold under the same conditions, i.e. when utility functions belong to the HARA class and are identical up to, at most, a translation factor (Cass and Stiglitz (1970), Rubinstein (1974), Milne (1979)). In our more general setting, however, the properties are distinct. Demands may aggregate yet may fail to exhibit fund separation and conversely. Fund separation implies effective completeness of the asset market while aggregation does not, i.e. Pareto efficiency may fail even if an economy aggregates. The implications of aggregation and fund separation for the properties of equilibria are discussed; useful extensions of traditional asset pricing models are obtained.

The next section of the paper describes the economy. Section three characterizes the set of economies which aggregate and studies the implications for asset pricing. Section 4 considers portfolio separation and examines its relationship with aggregation. In section 5 effective completeness is discussed and its relation to aggregation and fund separation assessed. 


\section{The Economy}

Economic activity extends over two periods, dates 0 and 1 . The uncertainty is represented by a finite set of states of nature $\mathbf{S}=\{1, \ldots, \mathrm{S}\}$, with generic element $\mathrm{s}$. Uncertainty resolves at date 1 .

A single perishable commodity is available at date zero and in each of the future states of nature. A commodity bundle is $\mathrm{c}=\left(\mathrm{c}_{0} ; \mathrm{c}_{1 \mathrm{~s}}, \mathrm{~s}=1, \ldots, \mathrm{S}\right){ }^{1}$ Assets are traded in the first period (date 0 ) and pay off in the second (date 1). There are A (real) assets. The matrix of asset payoffs (denominated in units of the consumption good) is $\mathrm{R}$ with $\mathrm{S}$ rows and A columns.

Assumption 2.1: R has full column rank.

A portfolio is a vector $\mathrm{x} \in \mathbb{R}^{\mathrm{A}}$; unlimited short-sales are allowed.

There is a finite number of investors, $\mathrm{h} \in H \equiv\{1, \ldots, \mathrm{H}\}$. The preferences of investor $\mathrm{h}$ are represented by a utility function $\mathrm{U}^{\mathrm{h}}$ defined over $\mathbb{R}_{+}^{S+1}$. Investor h's endowment of the consumption good is $\mathrm{e}^{\mathrm{h}} \equiv\left(\mathrm{e}_{0}^{\mathrm{h}}, \mathrm{e}_{1}^{\mathrm{h}}\right) \in \mathbb{R}_{+}^{\mathrm{S}+1}$ where $\mathrm{e}_{1}^{\mathrm{h}} \equiv\left(\mathrm{e}_{1 \mathrm{~s}}^{\mathrm{h}}, \mathrm{s}=1, \ldots, \mathrm{S}\right)$. The endowment vector $\mathrm{e}_{1}^{\mathrm{h}}$ has a unique decomposition

$$
\mathrm{e}_{1}^{\mathrm{h}}=\left(\mathrm{e}_{1}^{\mathrm{h}}\right)_{\perp \mathrm{Sp}[\mathrm{R}]}+\mathrm{Rx}_{\mathrm{e}}^{\mathrm{h}},
$$

where $\mathrm{Rx}_{\mathrm{e}}^{\mathrm{h}}$ is the orthogonal projection of $\mathrm{e}_{1}^{\mathrm{h}}$ on the column span of $\mathrm{R}, \mathrm{Sp}[\mathrm{R}]$, and $\left(\mathrm{e}_{1}^{\mathrm{h}}\right)_{\perp \mathrm{Sp}[\mathrm{R}]}$ is the orthogonal projection of $\mathrm{e}_{1}^{\mathrm{h}}$ on ${ }^{-} \mathrm{Sp}[\mathrm{R}]$, the orthogonal complement of $\mathrm{Sp}[\mathrm{R}]$. Without loss of generality we can assume that the agents have no initial endowment of assets (asset endowments can be thought of as a component of $\mathrm{Rx}_{\mathrm{e}}^{\mathrm{h}}$ ); the aggregate supply of assets then equals zero. We assume,

Assumption 2.2: For all $\mathrm{h} \in H, \mathrm{e}_{0}^{\mathrm{h}}>0$.

Assumption 2.3: For all $\mathrm{h} \in H$, the utility function $\mathrm{U}^{\mathrm{h}}: \mathbb{R}_{+}^{S+1} \rightarrow \mathbb{R}$ is twice continuously differentiable, strictly increasing and strictly quasi-concave. For all $c \in \mathbb{R}_{++}^{S+1}$, closure $\left\{\mathrm{y} \in \mathbb{R}_{+}^{\mathrm{S}+1}: \mathrm{U}^{\mathrm{h}}(\mathrm{y})>\mathrm{U}^{\mathrm{h}}(\mathrm{c})\right\} \subset \mathbb{R}_{++}^{\mathrm{S}+1}$.

A collection of endowments is $\mathbf{e} \equiv\left(\mathrm{e}^{\mathrm{h}}: \mathrm{h} \in H\right)$; a collection of utilities is $\mathbf{U} \equiv\left(\mathrm{U}^{\mathrm{h}}\right.$ : $\mathrm{h} \in H)$. An economy is a collection of endowments, utilities and a matrix of asset

\footnotetext{
1 Throughout the paper vectors are column vectors, though for convenience they are written as row vectors. The operator " " is used to denote the transpose of a vector or matrix when there is ambiguity.
} 
payoffs $(\mathbf{e}, \mathbf{U}, \mathbf{R})$. In what follows the payoff matrix $\mathrm{R}$ is fixed, and we consider the space of economies $\mathbf{\Xi} \equiv \mathbf{W} \otimes \mathbf{V}^{\mathrm{H}}$ with generic element $\xi=(\mathbf{e}, \mathbf{U})$, where $\mathbf{W}$ is the set of endowment distributions satisfying Assumption 2.2, $\mathbf{V}^{\mathrm{H}} \equiv \otimes_{\mathrm{h}=1}^{\mathrm{H}} \mathbf{V}$, where $\mathbf{V}$ is the set of utility functions satisfying Assumption 2.3 and $\otimes$ is the cartesian product. Let $\xi(\mathbf{U}) \equiv\left\{\xi \in \boldsymbol{\Xi}: \mathbf{U}=\left(\mathrm{U}^{\mathrm{h}}: \mathrm{h} \in H\right)\right\} \subset \boldsymbol{\Xi}$ denote the collection of economies with a given distribution of preferences.

Asset prices at date 0 are $p \in \mathbb{R}^{\mathrm{A}}$, normalized in terms of the good. Individual budget sets are,

$$
\boldsymbol{3}\left(\mathrm{p}, \mathrm{e}^{\mathrm{h}}\right)=\left\{\mathrm{c} \in \mathbb{R}_{+}^{\mathrm{S}+1}, \mathrm{x} \in \mathbb{R}^{\mathrm{A}}: \mathrm{c}_{0}+\mathrm{px} \leq \mathrm{e}_{0}^{\mathrm{h}}, \mathrm{c}_{1} \leq \mathrm{e}_{1}^{\mathrm{h}}+\mathrm{Rx}\right\}, \mathrm{h} \in H .
$$

Agents demand commodities and assets so as to maximize utility subject to their budget constraint

$$
\max _{\mathrm{c}, \mathrm{x}} \mathrm{U}^{\mathrm{h}}(\mathrm{c}) \text { s.t. }(\mathrm{c}, \mathrm{x}) \in \boldsymbol{3}\left(\mathrm{p}, \mathrm{e}^{\mathrm{h}}\right), \mathrm{h} \in H .
$$

Asset prices do not allow for arbitrage if and only if, $R x>0 \Rightarrow p x>0$. This condition is equivalent to $\mathrm{p} \in \mathcal{P} \equiv\left\{\mathrm{p} \in \mathbb{R}^{\mathrm{A}}: \mathrm{p}=\mathrm{R}^{\prime} \zeta\right.$ for some $\left.\zeta \in \mathbb{R}_{++}^{\mathrm{S}}\right\}$. For $\mathrm{p} \in \mathcal{P}, \xi \in \boldsymbol{\Xi}$ a solution to the individual optimization problem exists and is unique, for all $\mathrm{h}$ (Geanakoplos and Polemarchakis (1986)). Moreover, the individual demand for consumption and assets $\left(\mathrm{c}^{\mathrm{h}}, \mathrm{x}^{\mathrm{h}}\right)\left(\mathrm{p}, \mathrm{e}^{\mathrm{h}}\right), \mathrm{h} \in H$, is continuous and differentiable.

A consumption allocation is an array of consumption bundles $\left(\ldots, \mathrm{c}^{\mathrm{h}}, \ldots\right)$; an asset allocation is an array of portfolios $\left(\ldots, \mathrm{X}^{\mathrm{h}}, \ldots\right)$. A competitive equilibrium is a set of prices and a consumption-asset allocation such that at these prices consumption and asset holdings satisfy (2) and markets clear: $\Sigma_{\mathrm{h}} \mathrm{c}^{\mathrm{h}}=\Sigma_{\mathrm{h}} \mathrm{h}^{\mathrm{h}}$ and $\Sigma_{\mathrm{h}} \mathrm{x}^{\mathrm{h}}$ $=0$.

Under Assumptions 2.1-2.3 a competitive equilibrium exists. Let $\mathrm{p}(\xi)$ denote the set of equilibrium prices of economy $\xi, \xi \in \mathbf{\Xi}$.

Our objective is to characterize the set of economies for which the properties of aggregation, fund separation and effective completeness hold. For Arrow-Debreu economies, in which agents optimize their preferences over consumption subject to a single budget constraint, the issue of aggregation has been widely investigated. With incomplete markets but a single commodity the agents' optimization problem (2) is equivalent to the problem of maximizing the indirect utility over date 0 consumption and portfolio holdings subject to a unique budget constraint. The novelty of our approach consists in deriving the conditions for aggregation in terms of the direct preferences over consumption. We can then evaluate the effects of the presence of nonspanned endowments, which is the most important aspect of market incompleteness in this context. Similarly fund separation will be investigated as a property of the demand for current and future consumption (and our results show that this is the relevant notion in a general equilibrium model).

When there are multiple commodities at each date $(\mathrm{L}>1)$, the individual decision 
problem also includes a nontrivial decision to allocate a given income in each state among the various commodities. The conditions for aggregation derived in the paper for the case $\mathrm{L}=1$ apply to the indirect utility over income in each state, to obtain conditions for aggregation when $\mathrm{L}>1$. This indirect utility is the result of the standard problem of allocating a given income to the consumption of multiple goods in the same state with a complete set of spot markets. The solution to this problem has well known properties. Similar results hold for fund separation.

\section{Aggregation}

We characterize the set of economies which aggregate in the following sense,

Definition 3.1: We say that a collection of economies $\xi(\mathbf{U}) \subset \mathbf{\Xi}$ aggregates locally at the price $\mathrm{p}^{*}$ if and only if for any economy $\left(\mathbf{e}^{\prime}, \mathbf{U}\right) \in \xi(\mathbf{U})$ there exists an agent with preferences $\mathbf{U} \in \mathbf{V}$ such that the property

$$
\Sigma_{\mathrm{h}}\left(\mathrm{c}^{\mathrm{h}}, \mathrm{x}^{\mathrm{h}}\right)\left(\mathrm{p} ; \mathrm{e}^{\mathrm{h}}\right)=(\mathrm{c}, \mathrm{x})(\mathrm{p} ; \mathrm{e}) \in \operatorname{argmax}_{\mathrm{c}, \mathrm{x}} \mathrm{U}(\mathrm{c}) \text { s.t. }(\mathrm{c}, \mathrm{x}) \in \boldsymbol{3}(\mathrm{p}, \mathrm{e}),
$$

holds for all $(\mathrm{p}, \mathbf{e}) \in \mathrm{N}_{\varepsilon}\left(\mathrm{p}^{*}, \mathbf{e}^{\prime}\right) \cap\left(\rho_{\otimes} \mathbf{W}\right)$, where $\mathrm{e}=\Sigma_{\mathrm{h}} \mathrm{e}^{\mathrm{h}}$ and $\mathrm{N}_{\varepsilon}\left(\mathrm{p}^{*}, \mathbf{e}^{\prime}\right)$ is a $\varepsilon$-ball around $\left(\mathrm{p}^{*}, \mathbf{e}^{\prime}\right)$.

Remark 3.1: This definition of aggregation is essentially identical to the notions considered by Antonelli (1886) and Gorman (1953) under certainty; Rubinstein (1974) and Milne (1979) examine this concept in a setting with uncertainty, vNM preferences and endowments in the initial period only. Definition 3.1 imposes strong requirements: the aggregate demand must not only have the properties of an individual demand function (satisfy (3)), but also be independent of local changes in the distribution of endowments e. The local aspect of this definition is motivated by our interest in the structure of equilibria: the only relevant aspect is whether aggregation holds in a neighbourhood of equilibrium prices.

Definition 3.1 implies that, in the space of economies $\mathbf{\Xi}=\mathbf{W} \otimes \mathbf{V}^{\mathrm{H}}$, we seek restrictions on the collection of utilities $\mathbf{U}$, leaving the endowment distribution free (i.e. we seek subsets of the form $\mathbf{W} \otimes \mathbf{I}\left(\mathrm{p}^{*}\right)$, where $\left.\mathbf{I}\left(\mathrm{p}^{*}\right) \subseteq \mathbf{V}^{\mathrm{H}}\right)$. When markets are incomplete, however, the requirements of this definition will prove overly strong: aggregation holds for a much smaller class of economies than when markets are complete (see claim (ii) in Theorem 3.1 below). On the other hand, if we restrict attention to the subset of economies for which agents' endowments are spanned by the existing assets the incompleteness of the market does not interfere with the validity of aggregation (see claim (i) in Theorem 3.1). To define this weaker notion, 
let $\mathbf{W}_{\mathrm{sp}}$ be the subset of $\mathbf{W}$ satisfying the following condition,

$$
\mathrm{e}_{1}^{\mathrm{h}} \in \mathrm{Sp}[\mathrm{R}] \forall \mathrm{h} \in H \text {. }
$$

i.e. such that all the agents' endowments lie in the assets' span (therefore are marketed). Similarly, let $\mathbf{\Xi}_{\mathrm{p}} \equiv \mathbf{W}_{\mathrm{sp}} \otimes \mathbf{V}^{\mathrm{H}}$. We then say that a collection of economies $\xi_{\mathrm{sp}}(\mathbf{U})=\xi(\mathbf{U}) \cap \boldsymbol{\Xi}_{\mathrm{sp}}$ with spanned endowments aggregates locally at prices $p^{*}$ if the conditions of Definition 3.1 hold, restricted to the subset $\boldsymbol{\Xi}_{\mathrm{sp}}$.

The following restriction on the agents' preferences plays a crucial role in the analysis:

(IH) $\forall \mathbf{e}, \exists \mathrm{N}_{\varepsilon}\left(\mathrm{c}^{\mathrm{h}}\left(\mathrm{p}^{*}, \mathrm{e}^{\mathrm{h}}\right)\right) \subset \mathbb{R}_{++}^{S+1}, \alpha^{\mathrm{h}} \in \mathbb{R}^{S+1}$, and $\mathrm{V}: \mathbb{R}_{+}^{S+1} \rightarrow \mathbb{R}$ homothetic such that

$$
\mathrm{U}^{\mathrm{h}}\left(\mathrm{c}^{\mathrm{h}}\right)=\mathrm{V}\left(\alpha^{\mathrm{h}}+\mathrm{c}^{\mathrm{h}}\right) \forall \mathrm{c}^{\mathrm{h}} \in \mathrm{N}_{\mathrm{e}}\left(\mathrm{c}^{\mathrm{h}}\left(\mathrm{p}^{*}, \mathrm{e}^{\mathrm{h}}\right)\right), \text { for } \mathrm{h} \in H .
$$

If (IH) holds, we say that agents' preferences are almost identically locally homothetic at $\mathrm{p}^{*}$.

Theorem 3.1: Suppose that Assumptions 2.1-2.3 hold.

(i) The collection of economies $\xi_{\text {sp }}(\mathbf{U})$ with spanned endowments aggregates locally at $\mathrm{p}^{*}$, if and only if ( $\left.\mathbf{I H}\right)$ holds (preferences are almost identically locally homothetic at $\mathrm{p}^{*}$ ), and $\alpha_{1}^{\mathrm{h}} \in \mathrm{Sp}[\mathrm{R}] \forall \mathrm{h} \in H^{2}{ }^{2}$

(ii) The collection of economies $\xi(\mathbf{U})$ aggregates locally at $\mathrm{p}^{*}$ if and only if preferences are almost identically locally quadratic at $\mathrm{p}^{*}$ :

$$
\forall \mathbf{e}, \exists \mathrm{N}_{\varepsilon}\left(\mathrm{c}^{\mathrm{h}}\left(\mathrm{p}^{*}, \mathrm{e}^{\mathrm{h}}\right)\right) \subset \mathbb{R}_{+}^{S+1} \text { and Q positive definite: } \mathrm{U}^{\mathrm{h}}\left(\mathrm{c}^{\mathrm{h}}\right)=
$$

$$
-1 / 2\left(\alpha^{\mathrm{h}}+\mathrm{c}^{\mathrm{h}}\right)^{\prime} \mathrm{Q}\left(\alpha^{\mathrm{h}}+\mathrm{c}^{\mathrm{h}}\right), \mathrm{h} \in H,
$$

where $-\mathrm{Q}\left(\alpha^{\mathrm{h}}+\mathrm{c}^{\mathrm{h}}\right)>0$ over the relevant range of $\mathrm{c}^{\mathrm{h}}$.

\section{Proof of Theorem 3.1:}

Sufficiency: (i) Since preferences satisfy $(\mathbf{I H}), \mathrm{U}^{\mathrm{h}}\left(\mathrm{c}^{\mathrm{h}}\right)=\mathrm{V}\left(\alpha^{\mathrm{h}}+\mathrm{c}^{\mathrm{h}}\right)$ where $\mathrm{V}(\cdot)$ is homothetic in the relevant range of $\mathrm{c}^{\mathrm{h}}$. Moreover, the assumption $\left(\alpha^{\mathrm{h}}, \mathrm{e}^{\mathrm{h}}\right) \in \mathrm{Sp}[\mathrm{R}]$ implies the existence of a pair $\left(\mathrm{x}_{\alpha}^{\mathrm{h}}, \mathrm{x}_{\mathrm{e}}^{\mathrm{h}}\right)$ such that $\alpha_{1}^{\mathrm{h}}=\mathrm{Rx}_{\alpha}^{\mathrm{h}}$ and $\mathrm{e}_{1}^{\mathrm{h}}=\mathrm{Rx}_{\mathrm{e}^{\mathrm{e}}}^{\mathrm{h}}$. It follows that the individual optimization problem (2) is equivalent to,

$$
\begin{array}{ll}
\max _{c, \mathrm{x}} & \mathrm{V}\left(\alpha_{0}^{\mathrm{h}}+\mathrm{c}_{0}^{\mathrm{h}} ; \mathrm{R}\left(\mathrm{x}_{\mathrm{e}}^{\mathrm{h}}+\mathrm{x}_{\alpha}^{\mathrm{h}}+\mathrm{x}^{\mathrm{h}}\right)\right) \\
\text { s.t. } \quad & \alpha_{0}^{\mathrm{h}}+\mathrm{c}_{0}^{\mathrm{h}}+\mathrm{p}\left(\mathrm{x}_{\mathrm{e}}^{\mathrm{h}}+\mathrm{x}_{\alpha}^{\mathrm{h}}+\mathrm{x}^{\mathrm{h}}\right)=\alpha_{0}^{\mathrm{h}}+\mathrm{e}_{0}^{\mathrm{h}}+\mathrm{p}\left(\mathrm{x}_{\mathrm{e}}^{\mathrm{h}}+\mathrm{x}_{\alpha}^{\mathrm{h}}\right) \\
& \mathrm{c}_{0}^{\mathrm{h}} \geq 0 \\
& \mathrm{R}\left(\mathrm{x}_{\mathrm{e}}^{\mathrm{h}}+\mathrm{x}_{\alpha}^{\mathrm{h}}+\mathrm{x}^{\mathrm{h}}\right) \geq \mathrm{R} \mathrm{x}_{\alpha}^{\mathrm{h}} .
\end{array}
$$

\footnotetext{
${ }^{2}$ It is immediate to verify that aggregation also holds if $(\mathbf{I H})$ and the weaker condition $\left(\alpha_{1}^{\mathrm{h}}+\mathrm{e}_{1}^{\mathrm{h}}\right) \in \mathrm{Sp}[\mathrm{R}]$ are verified (thus, $\mathrm{e}_{1}^{\mathrm{h}}$ need not be in $\mathrm{Sp}[\mathrm{R}]$ ).
} 
Thus, under the assumptions of the Theorem the agents' indirect utility over date zero consumption and asset holdings is locally homothetic and identical across agents. Aggregation follows from a standard argument (see Gorman (1953), Chipman (1974)).

(ii) With quadratic preferences the first order conditions for agent h's optimization problem (2) are,

$$
\begin{aligned}
& \mathrm{Q}_{1}\left(\alpha^{\mathrm{h}}+\mathrm{c}^{\mathrm{h}}\right) \mathrm{p}=\left[\mathrm{Q}_{-1}\left(\alpha^{\mathrm{h}}+\mathrm{c}^{\mathrm{h}}\right)\right]^{\prime} \mathrm{R} \\
& \mathrm{c}_{0}^{\mathrm{h}}+\mathrm{px}^{\mathrm{h}}=\mathrm{e}_{0}^{\mathrm{h}} \\
& \mathrm{c}_{1}^{\mathrm{h}}=\mathrm{e}_{1}^{\mathrm{h}}+\mathrm{Rx}^{\mathrm{h}}
\end{aligned}
$$

where $\mathrm{Q}_{1}$ is the first row of $\mathrm{Q}$ and $\mathrm{Q}_{1}$ is the matrix composed of the remaining $\mathrm{S}$ rows. It is easy to verify that the solution to (5)-(7) is linear in the endowment vector $\mathrm{e}^{\mathrm{h}}$ and that the derivative of demand with respect to $\mathrm{e}^{\mathrm{h}}$ is identical across agents. Aggregation again follows.

Necessity: Definition 3.1 implies that a necessary condition for (local) aggregation is that the derivatives with respect to date zero income, ${ }^{3}$

$$
\left[\begin{array}{c}
\partial \mathrm{c}_{0}^{\mathrm{h}} / \partial \mathrm{e}_{0}^{\mathrm{h}} \\
\partial \mathrm{c}_{1}^{\mathrm{h}} / \partial \mathrm{e}_{0}^{\mathrm{h}}
\end{array}\right]=\mathrm{M}\left(\mathrm{D}^{2} \mathrm{U}^{\mathrm{h}}\right)^{-1} \mathrm{P}\left[\mathrm{P}^{\prime}\left(\mathrm{D}^{2} \mathrm{U}^{\mathrm{h}}\right)^{-1} \mathrm{P}\right]^{-1}
$$

where

$$
\mathrm{D}^{2} \mathrm{U}^{\mathrm{h}} \equiv \quad\left[\begin{array}{ll}
\mathrm{D}_{01}^{2} \mathrm{U}^{\mathrm{h}} & \mathrm{D}_{01}^{2} \mathrm{U}^{\mathrm{h}} \mathrm{R} \\
\mathrm{R}^{\prime} \mathrm{D}_{01}^{2} \mathrm{U}^{\mathrm{h}} & \mathrm{R}^{\prime} \mathrm{D}_{11}^{2} \mathrm{U}^{\mathrm{h}} \mathrm{R}
\end{array}\right], \quad \mathrm{M} \equiv\left[\begin{array}{ll}
1 & 0 \\
0 & \mathrm{R}
\end{array}\right], \mathrm{P} \equiv\left[\begin{array}{l}
1 \\
\mathrm{p}
\end{array}\right],
$$

are identical across agents $\left(a t\left(\mathrm{p}^{*}, \mathbf{e}\right)\right)$. This implies that the matrix of second derivatives $\mathrm{D}^{2} \mathrm{U}^{\mathrm{h}}$ must be the same, up to a scalar, for all $\mathrm{h} \in H$. When endowments are nonspanned this holds only if $\mathrm{D}^{2} \mathrm{U}^{\mathrm{h}}$ is independent of ${ }^{\mathrm{h}} \mathrm{c}$ (quadratic utility function). When endowments are spanned this holds only if utility functions satisfy $(\mathbf{I H})$; the vectors $\left(\mathrm{c}^{\mathrm{h}}+\alpha^{\mathrm{h}}\right)$ are then all collinear.

If Assumption 2.2 is modified to allow for preferences which are quasi concave (not strictly) in first period consumption (denote this weaker Assumption as 2.2') the conditions for aggregation become,

\footnotetext{
${ }^{3} \mathrm{D}_{\mathrm{ij}}^{2} \mathrm{U}^{\mathrm{h}}$ is the matrix of the second derivatives of $\mathrm{U}^{\mathrm{h}}$ with respect to $\mathrm{c}_{\mathrm{i}}^{\mathrm{h}}$ and $\mathrm{c}_{\mathrm{j}}^{\mathrm{h}}, \mathrm{i}, \mathrm{j}=0,1$
} 
Corollary 3.1: Suppose that Assumptions 2.1, 2.2' and 2.3 hold.

(i) Aggregation holds (locally at $\mathrm{p}^{*}$ ) for all collections of economies with spanned endowments $\xi_{\text {sp }}(\mathbf{U})$ if $\mathrm{U}^{\mathrm{h}}\left(\mathrm{c}^{\mathrm{h}}\right)=\alpha_{0}^{\mathrm{h}} \mathrm{c}_{0}^{\mathrm{h}}+\mathrm{U}_{1}^{\mathrm{h}}\left(\mathrm{c}_{1}^{\mathrm{h}}\right)$, for some arbitrary $\alpha_{0}^{\mathrm{h}}>0$ and some $\mathrm{U}_{1}^{\mathrm{h}}$ such that $\mathrm{U}^{\mathrm{h}}$ satisfies Assumption 2.2', $\mathrm{h} \in H$.

(ii) Aggregation holds (locally at $\left.\mathrm{p}^{*}\right)$ for all collections of economies $\{(\mathbf{e}, \mathbf{U}) \in \mathbf{\Xi}$ : $\mathrm{U}^{\mathrm{h}}=\alpha_{0}^{\mathrm{h}} c_{0}^{\mathrm{h}}+\mathrm{U}_{1}^{\mathrm{h}}\left(c_{1}^{\mathrm{h}}\right)$ where $\left(\mathrm{U}_{1}^{\mathrm{h}} \mathrm{h} \in H\right)$ satisfies the analogue of $(\mathbf{I H})$ and $\left(\alpha_{1}^{\mathrm{h}}+\mathrm{e}_{1}^{\mathrm{h}}\right)_{\perp<\mathrm{R}\rangle}=$ $\lambda^{\mathrm{h}} \eta$ for some $\left.\left(\eta, \lambda^{\mathrm{h}}\right) \in \mathbb{R}^{\mathrm{S}} \mathrm{x} \mathbb{R}, \mathrm{h} \in H\right\}$.

Proof of Corollary 3.1: Under the conditions of claim (ii) of the Corollary, the first order conditions for agent h's optimization problem become,

$$
\mathrm{p}=\mathrm{DV}_{1}\left(\lambda^{\mathrm{h}} \eta+\mathrm{R}\left(\mathrm{x}_{\mathrm{e}}^{\mathrm{h}}+\mathrm{x}_{\alpha}^{\mathrm{h}}+\mathrm{x}^{\mathrm{h}}\right)\right) \mathrm{R}
$$

for some $\lambda^{\mathrm{h}} \in \mathbb{R}$, where $\mathrm{DV}_{1}$ denotes the gradient of $\mathrm{Y}$. Homotheticity of ${ }_{1} \mathrm{~V}(\cdot)$ implies that the solution of $(8)$ is $\left(\mathrm{x}_{\mathrm{e}}^{\mathrm{h}}+\mathrm{x}_{\alpha}^{\mathrm{h}}+\mathrm{x}^{\mathrm{h}}\right)\left(\lambda^{\mathrm{h}}\right)^{-1}=\mathrm{f}(\mathrm{p})$, where $\mathrm{f}(\mathrm{p})$ is independent of h. Aggregation follows.

Under the conditions of claim (i) equation (8) becomes, $\mathrm{p}=\mathrm{DU}_{1}^{\mathrm{h}}\left(\mathrm{R}\left(\mathrm{x}_{\mathrm{e}}^{\mathrm{h}}+\mathrm{x}_{\alpha}^{\mathrm{h}}+\mathrm{x}^{\mathrm{h}}\right)\right) \mathrm{R}$. We conclude that $\mathrm{x}_{\mathrm{e}}^{\mathrm{h}}+\mathrm{x}_{\alpha}^{\mathrm{h}}+\mathrm{x}^{\mathrm{h}}=\mathrm{f}^{\mathrm{h}}(\mathrm{p})$. Again, aggregation follows.

This Corollary shows again that the conditions for aggregation when the endowment has a nonspanned component are very strong. On the other hand, with spanned endowments quasi-linear preferences imply aggregation as with complete markets.

What are the consequences of aggregation?

(i) Clearly it implies (if it holds at every equilibrium of an economy) that the equilibrium is unique and that the Jacobian of the aggregate demand at equilibrium is negative semidefinite (with the standard comparative statics implications). It also implies that nonspanned, zero net supply assets can be priced uniquely. Thus financial innovation (opening a new market in any of these assets) has no price effects; however, with nonspanned endowments it affects, generically, the equilibrium allocation and leads to a Pareto improvement.

(ii) More importantly, Theorem 3.1 yields a generalization of the standard CAPM (Sharpe (1964), Lintner (1965) and Mossin (1969)), the consumption CAPM (Breeden (1979)) and the CAPM with nonmarketed wealth (Mayers (1972)).

Let $\mathrm{X}_{\mathrm{e}}$ denote the market portfolio (i.e. $\mathrm{Rx}_{\mathrm{e}}$ is the spanned component of aggregate endowment $e), p_{e}$ its price and $\tilde{r}_{e}$ the random variable describing the rate of return $\mathrm{Rx}_{\mathrm{e}} / \mathrm{p}_{\mathrm{e}}$. Similarly, for any distribution of preferences satisfying (IH) define $\tilde{\mathrm{r}}_{a}$ and $\mathrm{p}_{\alpha}$ the return and the price of the portfolio $\mathrm{x}_{\alpha}$ (i.e. $\mathrm{Rx}_{\alpha}$ is the spanned component of the aggregate coefficient $\left.\alpha_{1}=\Sigma_{h} \alpha_{1}^{h}\right)$. Also, let $r_{f}$ denote the rate of return of the riskless asset, with payoff $\mathbf{1}=(1, \ldots, 1) \in \mathbb{R}^{\mathrm{S}}$. It is easily verified that, 


$$
\mathrm{q}=\left(\mathrm{q}_{1}, \ldots, \mathrm{q}_{\mathrm{s}}\right) \equiv\left[\mathrm{D}_{1} \mathrm{~V}(\alpha+\mathrm{e}) / \mathrm{D}_{0} \mathrm{~V}(\alpha+\mathrm{e})\right]\left(\left[\mathrm{D}_{1} \mathrm{~V}(\alpha+\mathrm{e}) / \mathrm{D}_{0} \mathrm{~V}(\alpha+\mathrm{e})\right] \mathbf{1}\right)^{-1},
$$

where $\mathrm{DV}=\left(\mathrm{D}_{0} \mathrm{~V}, \mathrm{D}_{1} \mathrm{~V}\right)$ is the utility gradient, is a probability measure.

Since $\tilde{\alpha}_{1}+\tilde{\mathrm{e}}_{1}=\tilde{\mathrm{r}}_{\alpha} \mathrm{p}_{\alpha}+\tilde{\mathrm{r}}_{\mathrm{e}} \mathrm{p}_{\mathrm{e}}+\left(\tilde{\alpha}_{1}+\tilde{\mathrm{e}}_{1}\right)_{\perp<\mathrm{R}\rangle}, \mathrm{q}$ is a function of $\tilde{\mathrm{r}}_{\mathrm{e}}$, linear when $\mathrm{V}(\cdot)$ is quadratic. Let $\tilde{r}$ be the rate of return on an arbitrary asset (whether spanned or not). We have,

Corollary 3.2 (generalized CAPM): If aggregation holds at equilibrium:

(i) under the conditions of Theorem 3.1(i) (i.e. with spanned endowments) $\tilde{\text { r satisfies }}$ the following generalized version of the consumption CAPM,

$$
E \tilde{\mathbf{r}}-\mathrm{r}_{\mathrm{f}}=-\operatorname{cov}\left(\frac{\mathrm{D}_{1} \mathrm{~V}\left(\alpha_{0}+\mathrm{e}_{0}, \tilde{\mathrm{r}}_{\alpha} \mathrm{p}_{\alpha}+\tilde{\mathrm{r}}_{\mathrm{e}} \mathrm{p}_{\mathrm{e}}\right)}{\mathrm{D}_{0} \mathrm{~V}\left(\alpha_{0}+\mathrm{e}_{0}, \tilde{\mathrm{r}}_{\alpha} \mathrm{p}_{\boldsymbol{\alpha}}+\tilde{\mathrm{r}}_{\mathrm{e}} \mathrm{p}_{\mathrm{e}}\right)}, \tilde{\mathrm{r}}\right) \operatorname{Sr} \mathrm{r}_{\mathrm{f}}=\hat{\boldsymbol{\beta}}\left[\mathrm{E} \tilde{\mathrm{r}}_{\mathrm{e}}-\mathrm{r}_{\mathrm{f}}\right]
$$

where expectations are taken with respect to the uniform probability measure, and $\hat{\boldsymbol{\beta}} \equiv \operatorname{cov}\left(\mathrm{D}_{1} \mathrm{~V} / \mathrm{D}_{0} \mathrm{~V}, \tilde{\mathrm{r}}\right) / \operatorname{cov}\left(\mathrm{D}_{1} \mathrm{~V} / \mathrm{D}_{0} \mathrm{~V}, \tilde{\mathrm{r}} \mathrm{e}\right)$;

(ii) under the conditions of Theorem 3.1(ii) returns satisfy a generalized version of the CAPM with nonmarketed (nonspanned) endowments,

$$
\tilde{\mathrm{Er}}-\mathrm{r}_{\mathrm{f}}=\lambda \operatorname{cov}\left(\mathrm{Q}_{-1}(\alpha+\mathrm{e}) \tilde{,} \tilde{\mathrm{r}}\right)=\boldsymbol{\beta}\left[\tilde{E r}_{\mathrm{e}}-\mathrm{r}_{\mathrm{f}} \mathbf{1}\right]
$$

where $\lambda \equiv-\mathrm{S}\left[1 \mathrm{Q}_{-1}(\alpha+\mathrm{e})\right]^{-1}$ and where $\beta \equiv \operatorname{cov}\left(\mathrm{Q}_{-1}(\alpha+\mathrm{e}), \tilde{\mathrm{r}}\right) / \operatorname{cov}\left(\mathrm{Q}_{-1}(\alpha+\mathrm{e}), \mathrm{r}_{\mathrm{e}}\right)$ represents the vector of (generalized) betas of the securities.

Proof of Corollary 3.2: Under the assumptions stated the price of an asset with payoff $\mathrm{r} \in \mathbb{R}^{\mathrm{S}}$ (marketed or not) is, $\mathrm{p}=\left[\mathrm{D}_{1} \mathrm{~V}(\alpha+\mathrm{e}) / \mathrm{D}_{0} \mathrm{~V}(\alpha+\mathrm{e})\right] \mathrm{r}$. In particular the riskless asset price is $1 / r_{\mathrm{f}}=\left[\mathrm{D}_{1} \mathrm{~V}(\alpha+\mathrm{e}) / \mathrm{D}_{\mathrm{b}} \mathrm{V}(\alpha+\mathrm{e})\right] \mathbf{1}$. Asset prices can then be written as, $\mathrm{p}=\left(\mathrm{r}_{\mathrm{f}}\right)^{-1} \mathrm{qR}$; thus $\mathrm{r}_{\mathrm{r}}=\mathrm{SE}[\tilde{\tilde{q}}]$. Since $\mathrm{E}[\tilde{\mathrm{q}} \mathrm{r}]=\operatorname{cov}(\tilde{\mathrm{q}}, \tilde{\mathrm{r}})+\mathrm{E}[\tilde{\mathrm{q}}] \mathrm{E}[\tilde{\mathrm{r}}]$ and $\mathrm{SE}[\tilde{q}]=1,(9)$ holds. Specialization to quadratic utility yields (10).

As Corollary 3.2 shows, aggregation implies that traded assets as well as unspanned assets in zero net supply satisfy a CAPM-like relationship: when endowments and translation factors are spanned the beta is a nonlinear function of the return of the market portfolio, $\tilde{\mathfrak{r}}$, (as well as of $\tilde{\tilde{r}_{x}}$ ); when endowments (and translation factors) are nonspanned and aggregation holds the beta is a ratio of two expressions which are 
linear functions of $\tilde{\mathrm{r}}_{\mathrm{e}}$ and $\tilde{\mathrm{r}}_{\alpha}$, but also depend on the nonmarketed component $\left(\alpha_{1}+\mathrm{e}_{1}\right)_{\perp<\mathrm{R}\rangle} \cdot$

\section{Fund Separation}

In this section we consider the property of portfolio separation defined as,

Definition 4.1: A collection of economies $\xi(\mathbf{U}) \subset \boldsymbol{\Xi}$ exhibits M-fund separation, locally at $\mathrm{p}^{*}$, if and only if for any $\mathrm{e}^{\prime}$ there exists a linear subspace of $\mathbb{R}^{\mathrm{S}}$, $\mathbf{M}(\mathrm{p}) \subset \operatorname{Sp}[\mathrm{R}]$, with $\mathbf{M} \equiv \operatorname{dim}(\mathbf{M}(\mathrm{p}))<\mathrm{A}$ such that,

$$
\mathrm{c}_{1}^{\mathrm{h}}\left(\mathrm{p} ; \mathrm{e}^{\mathrm{h}}\right) \in \mathbf{M}(\mathrm{p}) \forall \mathrm{h}, \forall(\mathrm{p}, \mathbf{e}) \in \mathrm{N}_{\mathrm{e}}\left(\mathrm{p}^{*}, \mathbf{e}^{\prime}\right) .
$$

This definition requires that the consumption demands of all agents in the economy lie in a M-dimensional subspace of $\mathrm{Sp}[\mathrm{R}]$ which is independent of local changes in the distribution of endowments,

$$
\mathrm{c}_{1}^{\mathrm{h}}\left(\mathrm{p} ; \mathrm{e}^{\mathrm{h}}\right)=\mathrm{R}\left[\Sigma_{\mathrm{m}=1}^{\mathrm{M}} \mathrm{x}_{\mathrm{m}}(\mathrm{p}) \lambda_{\mathrm{m}}^{\mathrm{h}}\left(\mathrm{p} ; \mathrm{e}^{\mathrm{h}}\right)\right], \forall(\mathrm{p}, \mathbf{e}) \in \mathrm{N}_{\mathrm{e}}\left(\mathrm{p}^{*}, \mathbf{e}^{\prime}\right) .
$$

Remark 4.1: Fund separation (in particular 2-fund separation) was originally discussed as a property of the portfolio demand of an agent in a mean-variance setting (Markowitz (1959), Tobin (1958)). The class of vNM preferences yielding fund separation was subsequently studied by various authors (notably, Cass and Stiglitz (1970), Brennan and Kraus (1976)). ${ }^{4}$ Our definition differs from this literature in two respects. First, fund separation is stated as a property of the demand for date one consumption. Any claim on fund separation as a property of the assets' demand would in fact not be invariant to endowment reallocations between dates zero and one which do not modify the agents' budget sets and hence their consumption demands. Second, fund separation is stated as a property of an economy with many agents. This is again motivated by our interest in its implications for equilibrium prices and allocations.

Theorem 4.1: Suppose that Assumptions 2.1-2.3 hold.

(i) The collection of economies $\xi_{\text {sp }}(\mathbf{U})$ with spanned endowments exhibits $\mathrm{M}$-fund separation locally at $\mathrm{p}^{*}$, for $\mathrm{M}<\mathrm{A}$ :

\footnotetext{
${ }^{4}$ An alternative approach identifies the class of distributions of asset returns which yield separation for arbitrary preferences (Ross (1978)).
} 
i1. if $\mathbf{U}$ satisfies (IH) (i.e. preferences are almost identically locally homothetic at $\left.\mathrm{p}^{*}\right), \alpha_{1}^{\mathrm{k}} \in \mathrm{Sp}[\mathrm{R}] \forall \mathrm{h}$ and $\mathrm{M}-1$ is the dimensionality of the space generated by the vectors $\left\{\alpha_{1}^{\mathrm{h}}, \mathrm{h} \in H\right\}$,

i2. alternatively, if, for all $\mathrm{h}, \mathrm{U}^{\mathrm{h}}\left(\mathrm{c}^{\mathrm{h}}\right)=\mathrm{U}_{0}^{\mathrm{h}}\left(\mathrm{c}_{0}^{\mathrm{h}}\right)+\mathrm{U}_{1}^{\mathrm{h}}\left(\mathrm{c}_{1}^{\mathrm{h}}\right)$ where $\mathrm{U}_{0}^{\mathrm{h}}$ is arbitrary and $\left(\mathrm{U}_{1}^{\mathrm{h}} \mathrm{h} \in H\right)$ satisfies the analogue of $(\mathbf{I H}), \alpha_{1}^{\mathrm{h}} \in \mathrm{Sp}[\mathrm{R}] \forall \mathrm{h}$ and $\mathrm{M}-1$ is the dimensionality of the span of $\left\{\alpha_{1}^{\mathrm{h}}, \mathrm{h} \in H\right\}$,

(ii) with arbitrary nonspanned endowments M-fund separation fails.

Proof of Theorem 4.1: (i1) From the proof of Theorem 3.1, when $\mathrm{e}_{1}^{\mathrm{h}} \in \mathrm{Sp}[\mathrm{R}]$ and (IH) holds we have $\left(\alpha_{0}^{\mathrm{h}}+\mathrm{c}_{0}^{\mathrm{h}}, \mathrm{xe}_{\mathrm{e}}^{\mathrm{h}}+\mathrm{x}_{\alpha}^{\mathrm{h}}+\mathrm{x}^{\mathrm{h}}\right)=\left(\mathrm{d}_{0}\left(\mathrm{p} ; \mathrm{e}^{\mathrm{h}}, \alpha^{\mathrm{h}}\right) ; \mathrm{d}_{1}\left(\mathrm{p} ; \mathrm{e}^{\mathrm{h}}, \alpha^{\mathrm{h}}\right)\right)$ where $\left(\mathrm{d}_{0}(\cdot) ; \mathrm{d}_{1}(\cdot)\right)$ are the solutions of (4).

Also $c_{1}^{\mathrm{h}}\left(\mathrm{p} ; \mathrm{e}^{\mathrm{h}}\right)=\mathrm{R}\left[\mathrm{d}_{1}\left(\mathrm{p} ; \mathrm{e}^{\mathrm{h}}, \alpha^{\mathrm{h}}\right)-\mathrm{x}_{\alpha}^{\mathrm{h}}\right] \in \operatorname{Sp}\left[\mathrm{Rd}_{1}\left(\mathrm{p} ; \Sigma_{\mathrm{h}} \mathrm{e}^{\mathrm{h}}, \Sigma_{\mathrm{h}} \alpha^{\mathrm{h}}\right) ; \mathrm{Rx}_{\alpha}^{\mathrm{h}}\right], \forall(\mathrm{p}, \mathbf{e}) \in \mathrm{N}_{\varepsilon}\left(\mathrm{p}^{*}, \mathbf{e}^{\prime}\right)$. Thus M-fund separation holds with $\mathrm{M}(\mathrm{p}) \equiv \operatorname{Sp}\left[\operatorname{Rd}_{1}\left(\mathrm{p} ; \Sigma_{\mathrm{h}} \mathrm{e}^{\mathrm{h}}, \Sigma_{\mathrm{h}} \alpha^{\mathrm{h}}\right) ; \mathrm{Rx}_{\alpha}^{1}, \ldots, \mathrm{Rx}_{\alpha}^{\mathrm{H}}\right]$, independent of $\mathrm{h}$ and of local changes in endowments.

(i2) Under the assumptions of claim i2. the individual choice problem can be rewritten as follows:

$$
\begin{array}{ll}
\max _{\mathrm{c}_{0}{ }^{x}} & \mathrm{U}_{0}^{\mathrm{h}}\left(\mathrm{c}_{0}^{\mathrm{h}}\right)+\mathrm{V}_{1}\left(\mathrm{R}\left(\mathrm{x}_{\mathrm{e}}^{\mathrm{h}}+\mathrm{x}_{\alpha}^{\mathrm{h}}+\mathrm{x}^{\mathrm{h}}\right)\right) \\
\text { s.t. } & \mathrm{c}_{0}^{\mathrm{h}}+\mathrm{px}^{\mathrm{h}} \leq \mathrm{e}_{0}^{\mathrm{h}} \\
& \mathrm{c}_{0}^{\mathrm{h}} \geq 0 \\
& \mathrm{R}\left(\mathrm{x}_{\mathrm{e}}^{\mathrm{h}}+\mathrm{x}_{\alpha}^{\mathrm{h}}+\mathrm{x}^{\mathrm{h}}\right) \geq \mathrm{Rx}_{\alpha}^{\mathrm{h} .} .
\end{array}
$$

where $\mathrm{V}_{1}: \mathbb{R}_{+}^{S_{+}} \rightarrow \mathbb{R}$ is homothetic (and independent of $\mathrm{h}$ ). It is easy to verify that solutions of (3') satisfy,

$$
\mathrm{x}^{\mathrm{h}}\left(\mathrm{p} ; \mathrm{e}^{\mathrm{h}}, \alpha^{\mathrm{h}}\right)=\left[\mathrm{e}_{0}^{\mathrm{h}}+\mathrm{p}\left(\mathrm{x}_{\mathrm{e}}^{\mathrm{h}}+\mathrm{x}_{\alpha}^{\mathrm{h}}\right)-\mathrm{c}_{0}^{\mathrm{h}}\left(\mathrm{p} ; \mathrm{e}_{0}^{\mathrm{h}}+\mathrm{p}\left(\mathrm{x}_{\mathrm{e}}^{\mathrm{h}}+\mathrm{x}_{\alpha}^{\mathrm{h}}\right)\right)\right] \mathrm{f}(\mathrm{p})-\left(\mathrm{x}_{\mathrm{e}}^{\mathrm{h}}+\mathrm{x}_{\alpha}^{\mathrm{h}}\right),
$$

where $f: \mathbb{R}^{\mathrm{A}} \rightarrow \mathbb{R}^{\mathrm{A}}$ and $\mathrm{c}_{0}^{\mathrm{h}}\left(\mathrm{p} ; \mathrm{e}_{0}^{\mathrm{h}}+\mathrm{p}\left(\mathrm{x}_{\mathrm{e}}^{\mathrm{h}}+\mathrm{x}_{\alpha}^{\mathrm{h}}\right)\right.$ are defined by:

$$
\begin{gathered}
\mathrm{f}(\mathrm{p}) \equiv \operatorname{argmax}_{\mathrm{y}} \mathrm{V}_{1}(\mathrm{Ry}) \text { s.t. } \mathrm{py}=1 . \\
\mathrm{c}_{0}^{\mathrm{h}}\left(\mathrm{p} ; \mathrm{e}_{0}^{\mathrm{h}}+\mathrm{p}\left(\mathrm{x}_{\mathrm{e}}^{\mathrm{h}}+\mathrm{x}_{\alpha}^{\mathrm{h}}\right)\right) \equiv \operatorname{argmax}_{\mathrm{c}}\left\{\mathrm{U}_{0}^{\mathrm{h}}(\mathrm{c})+\mathrm{V}_{1}\left(\left(\mathrm{e}_{0}^{\mathrm{h}}+\mathrm{p}\left(\mathrm{x}_{\mathrm{e}}^{\mathrm{h}}+\mathrm{x}_{\alpha}^{\mathrm{h}}\right)-\mathrm{c}\right) \operatorname{Rf}(\mathrm{p})\right)\right\} .
\end{gathered}
$$

Hence $c_{1}^{\mathrm{h}}\left(\mathrm{p} ; \mathrm{e}^{\mathrm{h}}, \alpha^{\mathrm{h}}\right)=\mathrm{e}_{1}^{\mathrm{h}}+\mathrm{Rx}^{\mathrm{h}}\left(\mathrm{p} ; \mathrm{e}^{\mathrm{h}}, \alpha^{\mathrm{h}}\right)$ is spanned by $\operatorname{Rf}(\mathrm{p})$ and $\mathrm{Rx}_{\alpha}^{\mathrm{h}} \quad$.M-fund separation follows.

(ii) The result follows from the definition of M-fund separation (since $e_{1}^{\mathrm{h}} \notin \operatorname{Sp}[\mathrm{R}]$ implies $\left.\mathrm{c}^{\mathrm{h}} \in \mathrm{Sp}[\mathrm{R}]\right)$.

Remark 4.2: 1 . The proof of Theorem 4.1 reveals that consumption demand has the structure,

$$
\mathrm{c}_{1}^{\mathrm{h}}\left(\mathrm{p} ; \mathrm{e}^{\mathrm{h}}\right)=\mathrm{R}\left[\mathrm{x}_{1}(\mathrm{p}) \lambda_{1}^{\mathrm{h}}\left(\mathrm{p} ; \mathrm{e}^{\mathrm{h}}\right)+\Sigma_{\mathrm{m}=2}^{\mathrm{M}} \mathrm{x}_{\mathrm{m}} \lambda_{\mathrm{m}}^{\mathrm{h}}\right], \forall(\mathrm{p}, \mathbf{e}) \in \mathrm{N}_{\mathrm{e}}\left(\mathrm{p}^{*}, \mathbf{e}^{\prime}\right) .
$$


The first fund is common across agents. Its composition depends on the agents' preferences (in fact only on their common component $\mathrm{V}$ ) and on $\mathrm{p}$; the demand for this fund varies with individual wealth and prices. The other funds depend only on the $\alpha^{\mathrm{h}}$ components of the agents' preferences and not on $\mathrm{p}$; the demand for these funds is also independent of $\mathrm{p}$. It is possible to show that the conditions stated in Theorem 4.1 are also necessary for fund separation as characterized in (13). However, we cannot claim that they are necessary for M-fund separation as defined in Definition 4.1 and described in (12).

2. For the case in which $\alpha^{\mathrm{h}}$ is state-independent for all $\mathrm{h}$ Theorem 4.1 generalizes the results of Cass and Stiglitz (1970) on monetary separation to arbitrary preferences. On the other hand the preferences in Cass and Stiglitz (1970) which exhibit general two-fund separation do not satisfy (13). This result of Cass and Stiglitz was extended by Lewbel and Perraudin (1995) who use the idea that separation is a lower rank property of the agents' demand functions. With complete markets the lower rank property holds for a class of preferences which is strictly larger than the class of homothetic preferences (Lewbel (1989)). With incomplete markets Lewbel and Perraudin (1995) provide conditions on the indirect utility function $\mathrm{W}(\mathrm{R}, \mathrm{p}, \mathrm{e})$ under which this lower rank property holds. The problem, however, is that this indirect utility depends not only on the original preferences of the agents over consumption, but also on the assets' payoffs and the distribution of endowments. Any fund separation claim in this setting thus fails to be robust with respect to perturbations in the assets' payoffs (or the endowments' distribution).

3. More importantly, as we will show in section 5 , the characterization of fund separation in (13) has important implications for efficiency which do not extend to economies satisfying only (12) (for instance the economies satisfying general twofund separation identified by Cass and Stiglitz).

Theorems 3.1 and 4.2 show that there is no systematic relation between the properties of aggregation and fund separation: aggregation does not imply, nor is implied by separation.

i. with nonspanned endowments fund separation fails but aggregation holds when preferences are quadratic of the form $\mathrm{U}^{\mathrm{h}}(\mathrm{c})=-1 / 2\left(\alpha^{\mathrm{h}}+\mathrm{c}^{\mathrm{h}}\right)^{\prime} \mathrm{Q}\left(\alpha^{\mathrm{h}}+\mathrm{c}^{\mathrm{h}}\right)$. The same is true if $(\mathbf{I H})$ holds and $\left(\alpha_{1}^{\mathrm{h}}+\mathrm{e}_{1}^{\mathrm{h}}\right) \in \mathrm{Sp}[\mathrm{R}]$ and if $\operatorname{dim} \operatorname{Sp}\left[\left(\alpha_{1}^{\mathrm{h}}\right)_{\mathrm{h}=1}^{\mathrm{H}}\right]>\mathrm{A}$.

ii. In case (i.2) of Theorem 4.2 fund separation holds even if the utility over time zero consumption is arbitrary (and hence aggregation fails).

The reason for the discrepancy between these properties is as follows. Aggregation holds only if the derivatives of consumption demands with respect to endowments are locally constant and identical across agents. On the other hand fund separation 
(as characterized in (13)) requires that all agents' date one consumption vectors belong to the asset span and their derivatives with respect to date zero savings be locally constant and identical across agents. Hence fund separation may hold (as in (ii) above) when savings depend nonlinearly on endowments, while it fails when the demand for date one consumption is linear in endowments but endowments are not in the span (as in the quadratic case).

Fund separation and aggregation also have different implications. Under the conditions of Theorem 4.1 a version of the CAPM as in Corollary 3.2 still holds, but we cannot say that there is a unique equilibrium or identify the Jacobian's properties. Other implications are discussed in section 5.

There is, however, a "core case" in which both aggregation and fund separation hold: with spanned endowments and (IH) (almost identical locally homothetic preferences) the vectors of consumption demands are locally affine functions of the endowments with common proportionality factor. If we restrict attention to vNM preferences, i.e. $\mathrm{U}^{\mathrm{h}}(\mathrm{c}) \equiv \mathrm{E}\left[\mathrm{u}^{\mathrm{h}}(\tilde{\mathrm{c}})\right]$, the "core case" reduces to the standard conclusion in the literature (see, e.g., Cass and Stiglitz (1970), Rubinstein (1974), Milne (1979)).

Corollary 4.1: Suppose that Assumptions 2.1-2.3 hold and that preferences are vNM. Then aggregation holds locally at $\mathrm{p}^{*}$, for all collections of economies with spanned endowments $\xi_{\mathrm{sp}}(\mathbf{U})$ if and only if for all $\mathrm{h} \mathrm{U}^{\mathrm{h}}$ belongs to the Hyperbolic Absolute Risk Aversion (HARA) class, $\mathrm{U}^{\mathrm{h}}$ is identical across agents up to at most the (now constant) translation factor and a riskless asset is marketed. Under these conditions 2-fund separation also holds.

\section{Effective Completeness of the Asset Market}

Let $\Perp$ denote the collinearity of two vectors. Effective completeness is defined as follows,

Definition 5.1: The asset market is effectively complete for the economy $\xi \in \mathbf{\Xi}$ if and only if for all equilibrium prices $\mathrm{p} \in \mathrm{p}(\xi)$ : $\mathrm{DU}^{\mathrm{h}}\left(\mathrm{c}^{\mathrm{h}}\left(\mathrm{p} ; \mathrm{e}^{\mathrm{h}}\right)\right){ }^{\Perp} \mathrm{DU}^{\mathrm{h}^{\prime}}\left(\mathrm{c}^{\mathrm{h}^{\prime}}\left(\mathrm{p} ; \mathrm{e}^{\mathrm{h}^{\prime}}\right)\right), \forall \mathrm{h}, \mathrm{h}^{\prime} \in H$.

Remark 5.1: Effective completeness requires that at every competitive equilibrium the vectors of the marginal rates of substitution between date one and date zero consumption are identical across agents, i.e. that the equilibrium allocation is Pareto optimal. When $\mathrm{A}=\mathrm{S}$ markets are complete and the condition above is always satisfied. Hence markets are also effectively complete. On the other hand, when 
$\mathrm{A}<\mathrm{S}$, markets are not, generically, effectively complete in the general space of economies $\mathbf{\Xi}$.

When markets are effectively complete, all nonspanned zero net supply assets can be priced uniquely; moreover, financial innovation has no effects on the equilibrium allocation and prices. Our next Theorem shows that effective completeness holds under the conditions obtained for fund separation.

Theorem 5.1: Suppose that Assumptions 2.1-2.3 hold. Under the conditions of Theorem 4.1 the market is effectively complete.

Proof of Theorem 5.1: From the proof of Theorem 4.1 (i1) we have $c_{1}^{\mathrm{h}}+\alpha_{1}^{\mathrm{h}} \Perp$ $\operatorname{Rd}_{1}\left(\mathrm{p} ; \Sigma_{\mathrm{h}} \mathrm{h}^{\mathrm{h}}, \Sigma_{\mathrm{h}} \alpha^{\mathrm{h}}\right)$. Under $(\mathbf{I H}), \mathrm{U}^{\mathrm{h}}\left(\mathrm{c}^{\mathrm{h}}\right)=\mathrm{V}\left(\mathrm{d}^{\mathrm{l}}+\mathrm{e}\right)$. It follows that the vectors of marginal utilities are identical across agents. In case (i2) $c_{1}^{\mathrm{h}}+\alpha_{1}^{\mathrm{h}} \Perp \operatorname{Rf}(\mathrm{p})$ so that $\mathrm{DU}_{1}^{\mathrm{h}}$ $=\mathrm{DV}_{1}(\operatorname{Rf}(\mathrm{p}))$; also from the first order conditions we get $\mathrm{DU}_{0}^{\mathrm{h}}=\mathrm{DV}_{1}{ }^{\prime} \mathrm{Rf}(\mathrm{p})$ for all $\mathrm{h}$. Therefore the utility gradients are identical across agents at all equilibrium prices.

On the other hand aggregation does not imply effective completeness. For instance under the conditions of Theorem 3.1(ii) (i.e. nonspanned endowments and quadratic preferences) aggregation holds but the equilibrium is not Pareto optimal. This confirms that welfare judgements cannot be based on aggregation. This was shown by Jerison (1984) through an example of an economy under certainty with diverse homothetic preferences and collinear endowments. Our results show the wider validity of this phenomenon: under the conditions of Theorem 3.1(ii) it is easy to find economies which aggregate (even with identical homothetic preferences) in which welfare comparisons across equilibria yield opposite results for the representative agent and all the agents in the economy. 


\section{References}

Antonelli, G. B., (1886), "Sulla Teoria Matematica della Economia Politica," Pisa, Tipografia del Falchetto.

Bottazzi, J. M. and T. Hens, (1996), "Excess Demand Functions and Incomplete Markets," Journal of Economic Theory, 68, 49-63.

Breeden, D., (1979), "An Intertemporal Asset Pricing Model with Stochastic Consumption and Investment Opportunities," Journal of Financial Economics, 7, 265-296.

Brennan, M. J. and A. Kraus, (1976), "The Geometry of Separation and Myopia," Journal of Financial and Quantitative Analysis, 11, 171-193.

Cass, D. and J. Stiglitz, (1970), "The Structure of Investor Preferences and Asset Returns and Separability in Portfolio Allocation: A Contribution to the Pure Theory of Mutual Funds," Journal of Economic Theory, 2, 122-160.

Chipman, J. S., (1974), "Homothetic Preferences and Aggregation," Journal of Economic Theory, 8, 26-38.

Debreu, G., (1974), "Excess Demand Functions," Journal of Mathematical Economics, 1, 15-23.

Geanakoplos, J. and H. Polemarchakis, (1986), "Existence, Regularity, and Constrained Suboptimality of Competitive Allocations when the Asset Market is Incomplete," in Uncertainty, Information and Communication, Essays in honor of K. Arrow, Vol. III, W. Heller, R. Starr and D. A. Starrett, eds, Cambridge University Press, 65-95.

Gorman, W., (1953), "Community Preference Fields," Econometrica, 21, 63-80.

Gottardi, P. and T. Hens, (1996), "On the Disaggregation of Excess Demand and Comparative Statics with Incomplete Markets and Nominal Assets," Discussion Paper, No. A-501, Universität Bonn.

Jerison, M., (1984), "Social Welfare and the Unrepresentative Representative Consumer," Discussion Paper, State University of New York at Albany.

Lewbel, A., (1989), "A Demand System Rank Theorem," Econometrica, 57, 701-705.

Lewbel, A. and W. Perraudin, (1995), "A Theorem on Mutual Fund Separation with General Preferences," Journal of Economic Theory, 65, 624-626.

Lintner, J., (1965), "The Valuation of Risky Assets and the Selection of Risky Investments in Stock Portfolios and Capital Budgets," Review of Economics and Statistics, 47, 13-37. 
Mantel, R., (1976), "Homothetic Preferences and Community Excess Demand Functions," Journal of Economic Theory, 12, 197-201.

Markowitz, H. M., (1959), Portfolio Selection: Efficient Diversification of Investment, Cowles Foundation Monograph 16, Yale University Press, New Haven, 1959.

Mayers, D., (1972), "Non-Marketable Assets and Capital Markets Equilibrium under Uncertainty," in M. C. Jensen (ed.), Studies in the Theory of Capital Markets, New York, Praeger Publishers Inc., 223-248.

Milne, F., (1979), "Consumer Preferences, Linear Demand Functions and Aggregation in Competitive Asset Markets," Review of Economic Studies, 46, 407-417.

Mossin, J., (1969), "Security Pricing and Investment Criteria in Competitive Markets," American Economic Review, 59, 749-756.

Ross, S. A., (1978), "Mutual Fund Separation in Financial Theory - The Separating Distributions," Journal of Economic Theory, 17, 254-286.

Rubinstein, M., (1974), "An Aggregation Theorem for Securities Markets," Journal of Financial Economics, 1, 225-244.

Sharpe, W., (1964), "Capital Asset Prices: A Theory of Market Equilibrium under Conditions of Risk," Journal of Finance, 19, 425-442.

Sonnenschein, H., (1974), "Market Excess Demand Functions," Econometrica, 40, 549-563.

Tobin, J., (1958), "Liquidity Preference as Behavior Towards Risk," Review of Economic Studies, 65-86. 


\section{Liste des publications au CIRANO .}

\section{Cahiers CIRANO / CIRANO Papers (ISSN 1198-8169)}

96c-1 Peut-on créer des emplois en réglementant le temps de travail ? / par Robert Lacroix

95c-2 Anomalies de marché et sélection des titres au Canada / par Richard Guay, JeanFrançois L'Her et Jean-Marc Suret

95c-1 La réglementation incitative / par Marcel Boyer

94c-3 L'importance relative des gouvernements : causes, conséquences et organisations alternative / par Claude Montmarquette

94c-2 Commercial Bankruptcy and Financial Reorganization in Canada / par Jocelyn Martel

94c-1 Faire ou faire faire : La perspective de l'économie des organisations / par Michel Patry

\section{Série Scientifique / Scientific Series (ISSN 1198-8177)}

97s-11 Aggregation, Efficiency and Mutual Fund Separation in Incomplete Markets / Jérôme B. Detemple et Piero Gottardi

97s-10 Global Strategic Benchmarking, Critical Capabilities and Performance of Aerospace Subcontractors / Élisabeth Lefebvre, Louis A. Lefebvre

97s-09 Reported Job Satisfaction: What Does It Mean? / Louis Lévy-Garboua, Claude Montmarquette

97s-08 Living on a Noisy and Dusty Street: Implications for Environmental Evaluation / Tagreed Boules, Robert Gagné et Paul Lanoie

97s-07 The Location of Comparative Advantages on the Basis of Fundamentals Only / Thijs ten Raa et Pierre Mohnen

97s-06 GARCH for Irregularly Spaced Financial Data: The ACD-GARCH Model / Eric Ghysels, Joanna Jasiak

97s-05 Can Capital Markets Create Incentives for Pollution Control? / Paul Lanoie, Benoît Laplante et Maité Roy

97s-04 La régie des services informatiques : Le rôle de la mesure et des compétences dans les décisions d'impartition / Benoit A. Aubert, Suzanne Rivard et Michel Patry

97s-03 Competition and Access in Telecoms: ECPR, Global Price Caps, and Auctions / Marcel Boyer

97s-02 L'économie des organisations : Mythes et réalités / Marcel Boyer

97s-01 Fixed Wages, Piece Rates, and Intertenporal Productivity: A Study of Tree Planters in British Columbia / Harry J. Paarsch et Bruce Shearer

96s-34 Structural Change and Asset Pricing in Emerging Markets / René Garcia et Eric Ghysels

96s-33 Monitoring of Pollution Regulation: Do Local Conditions Matter? / Catherine Dion, Paul Lanoie et Benoit Laplante

* Vous pouvez consulter la liste complète des publications du CIRANO et les publications elles-mêmes sur notre site World Wide Web à l'adresse suivante :

http://www.cirano.umontreal.ca/publication/page1.htm 